\title{
ANALISIS DAMPAK PERMUKIMAN KUMUH TERHADAP KAWASAN PESISIR KELURAHAN TALLO
}

\author{
(Analysis of The Impact of Slum Settlement on Coastal Area of Tallo Village) \\ Oleh: \\ Mega Ambriliani Robichin ${ }^{1)}$, Andi Tamsil ${ }^{2)}$ dan Siti Khadijah ${ }^{3)}$ \\ 1) PS Manajemen Pesisir dan Teknologi Kelautan PPS-UMI Makassar \\ 2) PS Pemanfaatan Sumberdaya Perikanan FPIK UMI Makassar \\ 3) PS Budidaya Perairan FPIK UMI Makassar
}

Korespondensi: ambrilianirr@gmail.com

Diterima: tanggal 25 Maret 2019; disetujui 31 April 2019

\begin{abstract}
The existence of slums in the coastal area has an impact on decreasing environmental quality both in the environment itself and the surrounding environment. This study aims to find out and analyze the factors that influence the impact of slums on the coastal areas of Tallo Village and the concepts and strategies of handling in an effort to minimize the impact. The study used a questionnaire on 133 samples, interviews and object documentation as instruments for primary data collection and literature and institutional studies for secondary data collection. The analytical tool used is multiple linear regression analysis, SWOT analysis and deskiptif analysis. The results of the analysis show the factors that influence the impact of slums on the coastal areas of Tallo Village, namely environmental factors, social factors and economic factors. The concept of handling slums in the coastal area of Tallo Village, namely 1). Prevention concepts (supervision, control \& community empowerment) and 2). The concept of improving the quality of the environment (renewal \& new development)
\end{abstract}

Keywords: Slum Settlements, Coastal Areas, Declining Quality Environment

\begin{abstract}
ABSTRAK
Keberadaan permukiman kumuh di kawasan pesisir berdampak pada penurunan kualitas lingkungan baik di lingkungan itu sendiri maupun lingkungan sekitarnya. Penelitian ini bertujuan untuk mengetahui dan menganalisis faktor-faktor yang mempengaruhi dampak permukiman kumuh terhadap kawasan pesisir Kelurahan Tallo serta konsep dan strategi penanganan dalam upaya meminimalisir dampak yang ditimbulkan. Penelitian menggunakan kuesioner pada 133 sampel, wawancara dan dokumentasi objek sebagai instrumen pengumpulan data primernya dan studi literatur dan instansional untuk pengumpulan data sekundernya. Alat analisis yang digunakan adalah analisis regresi linear berganda, analisis SWOT dan analisis deskiptif. Dari hasil analisis menunjukkan faktor-faktor yang mempengaruhi dampak permukiman kumuh terhadap kawasan pesisir Kelurahan Tallo yaitu faktor lingkungan, faktor sosial dan faktor ekonomi. Konsep penanangan permukiman kumuh di kawasan pesisir Kelurahan Tallo yaitu 1). Konsep Pencegahan (pengawasan, pengendalian \& pemberdayaan masyarakat) dan 2). Konsep Peningkatan kualitas lingkungan (pemugaran \& pembangunan baru)
\end{abstract}

Kata Kunci : Permukiman Kumuh, Kawasan Pesisir, Penurunan Kualitas Lingkungan 


\section{PENDAHULUAN}

Permasalahan permukiman kumuh perkotaan sering kali menjadi salah satu isu utama yang cukup kompleks, baik dari sisi fisik/lingkungan, ekonomi, sosial, serta sarana dan prasarananya. Determinan faktor dalam konteks penanganan kawasan permukiman kumuh sangat signifikan dipengaruhi oleh kondisi lingkungan, budaya, sosial dan ekonomi. Secara khusus keberadaan kawasan permukiman kumuh perkotaan berimplikasi terhadap paradigma buruk penyelenggaraan pemerintahan, dengan memberikan citra negatif akan ketidakberdayaan dan ketidakmampuan pemerintah dalam pengaturan pelayanan kehidupan dan penghidupan warganya.

Permasalahan permukiman kumuh di kawasan pesisir menjadi daya tarik untuk kegiatan penelitian dikarenakan mengingat bahwa Negara Indonesia merupakan negara maritim dan banyak kawasan di Negara Indonesia yang berbatasan langsung dengan laut. Permukiman kumuh di kawasan pesisir akan terus eksis dan berkembang apabila tingkat kesejahteraan masyarakat pesisir seperti nelayan masih rendah sehingga mereka masih belum cukup mampu untuk memperbaharui kondisi tempat tinggal mereka sendiri. Selain itu, kegiatan penelitian terhadap permukiman kumuh di kawasan pesisir merupakan salah satu bentuk kepedulian terhadap bencana alam yang kerapkali mengancam permukiman di kawasan pesisir.

Masalah permukiman kumuh di kawasan pesisir menjadi ukuran tingkat kualitas hidup yang rendah yang salah satunya dapat dilihat dari bentuk fisik permukiman. Permukiman kumuh identik dengan minimnya fasilitas, sarana dan prasarana serta dapat dikategorikan dalam rumah yang tidak layak huni. Rumah tidak layak huni adalah rumah atau tempat tinggal yang dibangun dari bahan material bekas (keterbatasan) dan berada pada lokasi yang tidak cocok untuk kegiatan permukiman (Ditjen Perkim, 2002).

\section{METODE PENELITIAN}

Penelitian ini dilaksanakan selama kurang lebih 2 (dua) bulan, yakni pada bulan November 2018 sampai Januari 2019. Lokasi penelitian terletak di kawasan pesisir Kelurahan Tallo yakni RW 004 dan RW 005. 


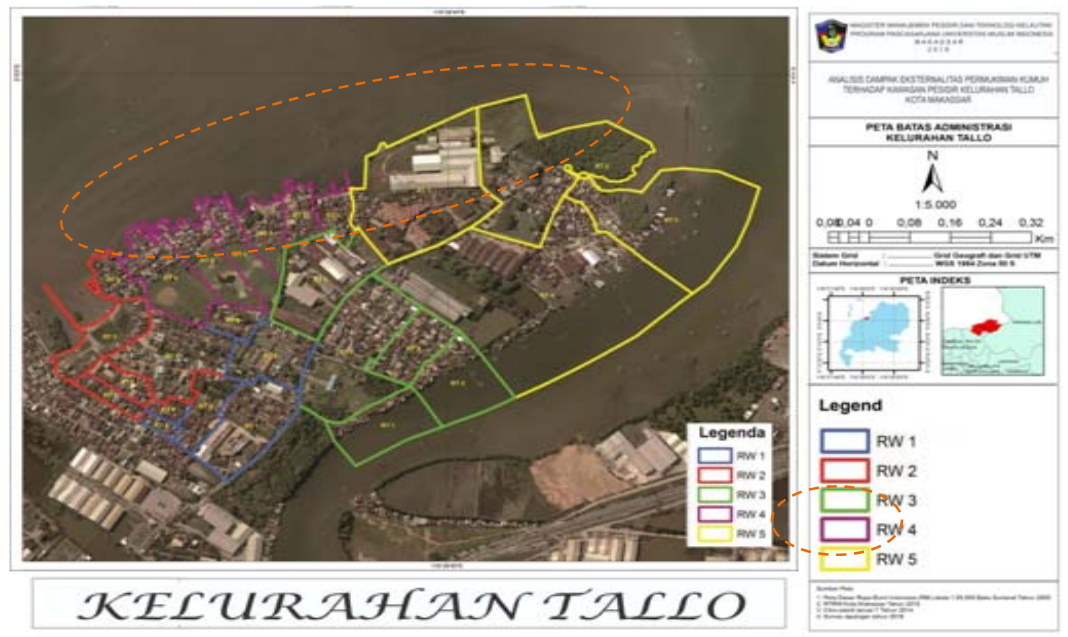

Gambar 1. Peta Lokasi Penelitian

Penelitian menggunakan 2 (dua) jenis sumber data yaitu data primer dan data sekunder. Teknik pengambilan data pada penelitian ini yaitu observasi lapangan, kuisioner dengan 133 sampel, wawancara (in-depth interview) dengan masyarakat maupun pihak terkait, dan dokumentasi dengan tujuan mengumpulkan dokumen-dokumen dan foto-foto di lapangan yang mendukung penelitian.

Sampel penelitian berada pada 2 (dua) lokasi di kawasan pesisir yakni RW 004 yang merupakan kawasan pesisir pantai dan RW 005 merupakan kawasan bantaran sungai Tallo. Teknik penentuan sampel sebagai responden dalam penelitian ini diambil secara acak (random sample) dari 200 kepala rumah tangga di kedua lokasi dimana secara teoritis kedua lokasi tersebut diatas mempunyai probabilitas atau kesempatan untuk dipilih menjadi sampel. Maka untuk penelitian kali ini peneliti menggunakan salah satu metode yang akan digunakan untuk menentukan jumlah sampel adalah menggunakan rumus (Sugiyono,2010), sebagai berikut:

$$
n=\frac{N}{1+N \cdot e^{2}}
$$

Dimana:

$\mathrm{n}=\quad$ Jumlah sampel

$\mathrm{N}=\quad$ Jumlah populasi

$\mathrm{e}=$ Batas toleransi kesalahan (error tolerance)

Batas toleransi kesalahan ini dinyatakan dengan persentase. Semakin kecil toleransi kesalahan, semakin akurat sampel menggambarkan populasi. Misalnya, penelitian dengan batas kesalahan 5\% berarti memiliki tingkat akurasi 95\%. 
$\mathrm{n}=\mathrm{N} /\left(1+\mathrm{N} . \mathrm{e}^{2}\right)=200 / 1+200 \mathrm{x}$ $0,05 \times 0,05=133,33=133($ Dibulatkan keatas)

Jadi besar sampel yang diperlukan adalah $133 \mathrm{KK}$.

Alat analisis yang digunakan adalah analisis regresi linear berganda, analisis SWOT dan analisis deskiptif. Masingmasing analisis tersebut dijelaskan sebagai berikut :

\section{Analisis Regresi Linear Berganda} adalah analisis hubungan antara dua atau lebih variabel bebas $(\mathrm{X})$ terhadap satu variabel terikat (Y) dengan asumsi Y merupakan fungsi dari X. Hasil analisis regresi adalah berupa koefisien untuk masing- masing variabel bebas. Koefisien ini diperoleh dengan cara memprediksi nilai variabel terikat dengan suatu persamaan. Koefisien regresi dihitung dengan dua tujuan sekaligus. Pertama meminimumkan penyimpangan antara nilai aktual dan nilai estimasi variabel terikat berdasarkan data yang ada. (Hartono, 2012)

Dalam analisis regresi, selain mengukur kekuatan hubungan antara dua variabel atau lebih, juga melanjutkan arah hubungan antara variabel terikat dengan variabel bebas. Yang mana tujuannya adalah untuk mengetahui apakah variabel bebas (Lingkungan, Sosial, Ekonomi) secara bersama-sama mempengaruhi variabel terikat (Dampak Permukiman Kumuh) Secara matematis, hubungan variabel tersebut dapat dinyatakan dalam bentuk sebagai berikut :

$$
Y=b_{0}+b_{1} X_{1}+b_{2} X_{2}+b_{3} X_{3}
$$

Dimana :

$\mathrm{Y}=$ Dampak Permukiman Kumuh

$\mathrm{B}_{0}=$ Konstanta

$\mathrm{X}_{1}=$ Variabel 1 (Lingkungan)

$\mathrm{X}_{2}=$ Variabel 2 (Sosial)

$\mathrm{X}_{3}=$ Variabel 3 (Ekonomi)

$\mathrm{B}_{\mathrm{i}}=$ Koefisien parameter variabel bebas, $\mathrm{i}=1,2,3$

Analisis SWOT adalah instrumen yang digunakan untuk melakukan analisis strategis. Menurut Drs. Robert Simbolon, MPA (1999), analisis SWOT merupakan suatu alat yang efektif dalam membantu menstrukturkan masalah, terutama dengan melakukan analisis atas lingkungan strategis, yang lazim disebut sebagai lingkungan internal dan lingkungan eksternal.

Dalam lingkungan internal dan eksternal ini pada dasarnya terdapat empat unsur yang selalu dimiliki dan dihadapi, yaitu secara internal memiliki sejumlah

kekuatan-kekuatan 
(Strengths) dan kelemahan- Kelurahan yang berbatasan dengan kelemahan (Weaknesses), dan secara kawasan pesisir yakni RW 02, RW 03, eksternal akan berhadapan dengan RW 04 dan RW 05 yang mana RW 02 berbagai peluang-peluang dan RW 04 berbatasan langsung (Oppotunities) dan ancaman- dengan pesisir pantai sedangkan RW ancaman (Threats).

03 dan RW 05 berbatasan langsung

Analisis Deskriptif dipergunakan untuk dengan DAS.

menggambarkan dan menguraikan

Profil Permukiman Kumuh kondisi dari perencanaan yang ada, Kelurahan Tallo dalam hal ini terkait dengan karakteristik wilayah dan faktor- faktor yang mempengaruhi dampak

Kawasan permukiman kumuh di Kelurahan Tallo dengan luas sebesar permukiman kumuh terhadap kawasan 30,00 Ha, berdasarkan SK Walikota Kota Makassar Nomor: pesisir Kelurahan Tallo serta konsep dan strategi penataan permukiman 050.05/1341/Kep/IX/2014.

kumuh dalam upaya meminimalisir dampaknya terhadap kawasan pesisir Kelurahan Tallo.

\section{HASIL DAN PEMBAHASAN}

\section{Gambaran Umum Kelurahan Tallo}

Secara administratif, Kelurahan Tallo terbagi menjadi 5 Rukun Warga (RW) dan terdiri dari 26 Rukun Tetangga (RT) dengan luas wilayah mencapai luas $\pm 63,33$ Ha yang terdiri dari daratan dan sebagian besar wilayah laut serta Sungai Tallo.

Kelurahan Tallo terdiri dari 5 RW Karakteristik kawasan permukiman kumuh Kelurahan Tallo merupakan kawasan sub pusat kota, pusat kegiatan sosial ekonomi dan Kawasan cagar budaya (Makam Raja-Raja Tallo). Informasi dasar tersebut diuraikan berdasarkan 7 aspek penilaian permukiman kumuh serta keberadaan lokasi dan tipologi, karakteristik, identifikasi legalitas lahan, identifikasi kondisi kekumuhan dan pertimbangan lainnya. Profil permukiman kumuh di Kelurahan Tallo dapat dilihat pada Tabel berikut :

(Rukun Warga), yang diantaranya terdapat 5 RW yang berbatasan langsung dengan kawasan pesisir. 
Tabel 1 Profil Permukiman Kumuh Kelurahan Tallo

\begin{tabular}{|c|c|c|c|}
\hline \multicolumn{4}{|c|}{ Informasi Lokasi dan Tipologi } \\
\hline \multicolumn{2}{|l|}{ Provinsi } & \multicolumn{2}{|l|}{ Sulawesi Selatan } \\
\hline \multicolumn{2}{|l|}{ Kota } & \multicolumn{2}{|l|}{ Makassar } \\
\hline \multicolumn{2}{|l|}{ Kecamatan } & \multicolumn{2}{|l|}{ Tallo } \\
\hline \multicolumn{2}{|l|}{ Kelurahan } & \multicolumn{2}{|l|}{ Tallo } \\
\hline \multicolumn{2}{|l|}{ Luas Permukiman } & \multicolumn{2}{|l|}{$30 \mathrm{Ha}$} \\
\hline \multicolumn{2}{|l|}{ Jumlah Penduduk } & \multicolumn{2}{|l|}{8101 Jiwa } \\
\hline \multicolumn{2}{|l|}{ Jumlah Kepala Keluarga (KK) } & \multicolumn{2}{|l|}{$1921 \mathrm{KK}$} \\
\hline \multicolumn{2}{|l|}{ Jumlah Bangunan } & \multicolumn{2}{|l|}{1499 Unit } \\
\hline \multicolumn{2}{|l|}{ Legalitas Lokasi } & \multicolumn{2}{|l|}{ Tercantum dalam SK Walikota } \\
\hline \multicolumn{2}{|l|}{ Tipologi Lokasi Kumuh } & \multicolumn{2}{|l|}{ Dataran Rendah dan Tepi Air } \\
\hline \multicolumn{4}{|c|}{ Karakteristik Lokasi } \\
\hline \multirow{2}{*}{\multicolumn{2}{|c|}{ Karakteritik Kawasan }} & \multicolumn{2}{|l|}{ Kawasan Sub Pusat Perkotaan } \\
\hline & & \multicolumn{2}{|l|}{ Pusat Kegiatan Sosial Ekonomi } \\
\hline \multicolumn{4}{|c|}{ Identifikasi Legalitas Lahan } \\
\hline \multicolumn{2}{|l|}{ Status Lahan } & \multicolumn{2}{|l|}{ Legal } \\
\hline \multicolumn{2}{|c|}{ Kesesuaian dengan Peruntukan RTRW } & Sesuai dengan Peruntukan RTRW & \\
\hline & den & tifikasi Kondisi Kekumuhan & Volume \\
\hline Kondisi Bangunan Hunian & & Jumlah bangunan tidak memenuhi persyaratan teknis & 442 Unit \\
\hline Kondisi Jalan Lingkungan & & Panjang jalan eksisting & $9.352 \mathrm{M}$ \\
\hline & & Panjang jalan dengan permukaan rusak & $3.136 \mathrm{M}$ \\
\hline Kondisi Penyediaan Air Minum & & Jumlah KK tidak terakses air minum aman & $726 \mathrm{KK}$ \\
\hline & & $\begin{array}{l}\text { Jumlah KK tidak terpenuhi kebutuhan Air Minum } \\
\text { minimalnya }\end{array}$ & $1.190 \mathrm{KK}$ \\
\hline Kondisi Drainase Lingkungan & & Luas kawasan yang terkena genangan & $2,78 \mathrm{Ha}$ \\
\hline & & Panjang saluran drainase eksisting & $8.859 \mathrm{M}$ \\
\hline & & Panjang saluran drainase yang tidak dipelihara & $7.239 \mathrm{M}$ \\
\hline & & Panjang saluran drainase rusak & $3.462 \mathrm{M}$ \\
\hline Kondisi Pengelolaan Air Limbah & & $\begin{array}{l}\text { Jumlah KK tidak terakses sistem air limbah sesuai standar } \\
\text { teknis }\end{array}$ & $482 \mathrm{KK}$ \\
\hline & & $\begin{array}{l}\text { Jumlah KK dengan sapras air limbah tidak sesuai persyaratan } \\
\text { teknis }\end{array}$ & $708 \mathrm{KK}$ \\
\hline Kondisi Pengolahan Persampahan & & $\begin{array}{l}\text { Jumlah KK dengan sarpras pengolahan sampah yang tidak } \\
\text { sesuai standar teknis }\end{array}$ & $1.076 \mathrm{KK}$ \\
\hline & & $\begin{array}{l}\text { Jumlah KK dengan sistem pengolahan sampah tidak sesuai } \\
\text { standar teknis }\end{array}$ & $294 \mathrm{KK}$ \\
\hline & & $\begin{array}{l}\text { Jumlah KK dengan sarpras pengolahan sampah tidak } \\
\text { terpelihara }\end{array}$ & $1.472 \mathrm{KK}$ \\
\hline Kondisi Proteksi Kebakaran & & $\begin{array}{l}\text { Jumlah bangunan tidak terlayani prasarana proteksi } \\
\text { kebakaran }\end{array}$ & 380 Unit \\
\hline & & Jumlah bangunan tidak terlayani sarana proteksi kebakaran & 1.482 Unit \\
\hline & & Pertimbangan Lain & \\
\hline $\begin{array}{l}\text { Kondisi Sosial dan Ekonomi } \\
\text { Masyarakat }\end{array}$ & & $\begin{array}{l}\text { Sistem ekonomi masyarakat subsisten dan komersil } \\
\text { Dominan mata pencaharian masyarakat di sektor informal }\end{array}$ & \\
\hline
\end{tabular}




\section{Penilaian Prioritas kawasan Kumuh}

Tabel 2 Penilaian Prioritas Kawasan Kumuh Kota Makassar

\begin{tabular}{|c|c|c|c|c|c|c|c|c|c|c|}
\hline No. Luas & Noma Kowsasan & Kowssan Kumuh SK (Kelurahan) & Kottegoni & $\begin{array}{l}\text { Pertimbengan } \\
\text { lain }\end{array}$ & $\begin{array}{c}\text { STATUS } \\
\text { IMB }\end{array}$ & $\begin{array}{l}\text { STAUS } \\
\text { SHM }\end{array}$ & $\begin{array}{l}\text { Kesesuaian } \\
\text { dengen RTRW }\end{array}$ & Korahteristik & Klasitilase & Prionitas \\
\hline 275,2 & Msriso & $\begin{array}{l}\text { Bontorannu, Kampung buyarg, Lette, Mariso, } \\
\text { Mottosngin, Pernambungan }\end{array}$ & Berat & Tirgg: & $(t)(-)$ & $(+)(-)$ & $(+)$ & $\begin{array}{l}\text { Batas Darrotan Rekilamasi, } \\
\text { Krowasan Kota Lama }\end{array}$ & $\mathrm{A}_{2}$ & 1 \\
\hline $\begin{array}{ll}6394,3 \\
\end{array}$ & Pangiksarg Tallo & 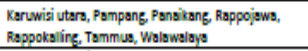 & Berat & Tirgsi & $(t)(-)$ & $(+1)(-1)$ & $(t)$ & Kowasan pusat kota & A.2 & 1 \\
\hline $7 \quad 301,0$ & $\begin{array}{l}\text { Pootere Tallo } \\
\text { Bontosida }\end{array}$ & 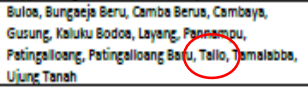 & Beret & Tirses: & {$[+1](-1)$} & $(+1)(-1)$ & $(t)(-)$ & $\begin{array}{l}\text { Tepisn air, kawassan } \\
\text { pelisbuhan Iams }\end{array}$ & A2 & 1 \\
\hline $11 \quad 211,6$ & $\begin{array}{l}\text { Mongesa } \\
\text { Porrengtambung }\end{array}$ & Mangass, Parangtambung & Berat & Tirggi & $(t)(-1)$ & $(+)(-1)$ & $(t)(-)$ & Tepisn air & A.2 & 1 \\
\hline $12,30,2$ & Tonjung Nerdeks & Taniung Merdelia & Berat & Tirgs: & $(+1) \cdot(-1)$ & $(+1)(-1)$ & $(+)$ & Tepisnair & $A 2$ & 1 \\
\hline $13 \quad 54,5$ & Mscciri Sombola & Moccini sombals & Berat & Tirgej & $(t)(-1)$ & $(+1)(-1)$ & $(+)(-)$ & Tepisn \&ir & A.2 & 1 \\
\hline $14 \quad 41,5$ & Barombong & Barombong & Berat & Tirgge & $(t)(-1)$ & $(+1)(-1)$ & (t) & Tepisn air & A.2 & 1 \\
\hline $\begin{array}{ll}16 & 14,0 \\
\end{array}$ & Untis & Untis & Berat & Tirgeg & $(t)(-1)$ & $(+1)(-1)$ & $(+)$ & Tepisn \&ir & $\mathrm{A} 2$ & 1 \\
\hline $21,20,6$. & Barrong Lompo & Barang Lompo & Berat & Tirgej & $(t)(-1)$ & $(+1)(-1)$ & $(+)$ & Tepisn air & A2 & 1 \\
\hline $3,216,9$, & Mongiang Tamolaste & 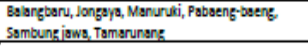 & sedare & Tirgs: & $(+1)-1$ & $(+1)(-1)$ & $(+)$ & Kowasan Kota Lama & 82 & 2 \\
\hline $8 \quad 392,2$ & Ponsikutkang & Batua, Borong, Pandeng & Sectarg & Tirgej & $(t+1)(-1)$ & $(+1)(-1)$ & $(+)$ & Kowasan pusat kots & 82 & 2 \\
\hline $25,979,6$ & Tomsisnres & 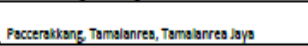 & Sectarg & Tirgej: & $(t)(-)$ & $(+1)(-1)$ & $\frac{(+)}{(+)}$ & $\begin{array}{l}\text { Kowasan pengembangan } \\
\text { kots }\end{array}$ & 82 & 2 \\
\hline $\begin{array}{ll}22 & 9,7 \\
\end{array}$ & Barang Cosdi & Barrong coddi & Berat & Sedang & {$[+](-)$} & $(+1)(-1)$ & $(+)$ & Tepisn air & A4 & 4 \\
\hline $\begin{array}{ll}23 & 21,3 \\
\end{array}$ & Kodingareng & Kodingsereng & Berat & Sedang & $(t)(-)$ & $(+)(-1)$ & $(+)$ & Tepisn air & A4 & 4 \\
\hline $\begin{array}{ll}24 & 94,6 \\
\end{array}$ & Rappoocini Utara & Banta-osntserng, Buaksna, Roppocini & Berat & Sedang & $(t)(-1)$ & $(+)(-1)$ & $(+)$ & Kowasan pusat kota & $\mathrm{A4}$ & 4 \\
\hline $5,343,2$ & Msiassar Bontoals & 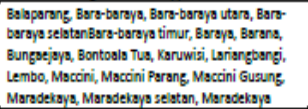 & secorrs & Sedang & $(t)(-)$ & $(t)(-)$ & & Kowasan pusat kots & 84 & 3 \\
\hline
\end{tabular}

Berdasarkan tabel diatas dapat Lingkungan adalah semua benda dan dilihat bahwa di Kota Makassar sendiri kondisi termasuk didalamnya manusia dalam penilaian prioritas kawasan dan aktifitasnya, yang terdapat ruang kumuh Kelurahan Tallo masuk pada dimana manusia berada dan kategori "Kumuh Berat" dengan mempengaruhi kelangsungan hidup karakteristik lokasi tepian air yang serta kesejahteraan hidup.

mempertimbangkan aspek selain 7 Lingkungan yang dimaksud dalam indikator 19 kriteria kekumuhan. penelitian ini adalah lingkungan Klasifikasinya A2 dengan prioritas 1, permukiman kumuh di Kelurahan Tallo artinya diprioritaskan pertama dalam yang mana memberikan dampak penanangan kekumuhan di Kota terhadap kawasan sekitar khususnya Makassar bersama kelurahan lainnya kawasan pesisir dan bantaran sungai. yang masuk dalam kategori tersebut. Berdasarkan hasil telaah pustaka dan

Faktor-Faktor yang Mempengaruhi Dampak Permukiman Kumuh

Terhadap Kawasan Pesisir

Kelurahan Tallo

kuesioner, faktor lingkungan tolok ukur dampak permukiman kumuh terhadap kawasan pesisir Kelurahan Tallo diantaranya kondisi bangunan hunian, kondisi jalan lingkungan, kondisi drainase lingkungan, kondisi 
ketersediaan air bersih, kondisi pengelolaan limbah, kondisi pengelolaan persampahan dan kondisi ketersediaan proteksi kebakaran.

Sosial merupakan sekelompok manusia yang dengan secara individu terlibat dalam berbagai aktifitas atau kegiatan secara bersama-sama. (Paul Ernest)

Sosial yang dimaksudkan dalam penelitian ini adalah yang terkait dengan perilaku masyarakat, partisipasi masyarakat serta kepedulian pemerintah di kawasan permukiman kumuh yang secara langsung maupun tidak langsung memberikan dampak terhadap kawasan pesisir Kelurahan Tallo.

Ekonomi yang dimaksudkan dalam penelitian ini meliputi pekerjaan, pendapatan, usaha penunjang dan status kepemilikan lahan dan bangunan di kawasan permukiman kumuh yang secara langsung maupun tidak langsung memberikan dampak terhadap kawasan pesisir Kelurahan Tallo.

\section{Hasil Pengujian Analisis Regresi Linear Berganda Terhadap Faktor- Faktor Yang Mempengaruhi Dampak Permukiman Kumuh Terhadap Kawasan Pesisir}

Hasil analisis menggunakan analisis regresi linear berganda atas variabel lingkungan, sosial dan ekonomi terhadap dampak permukiman kumuh adalah sebagai berikut :

\section{Hasil Uji F}

Untuk mengetahui faktor - faktor yang berpengaruh secara bersama sama atau uji hipotesis secara simultan antara antara variabel $\mathrm{X}_{1}$ (lingkungan), variabel $\mathrm{X}_{2}$ (sosial), dan variabel $\mathrm{X}_{3}$ (ekonomi), terhadap permukiman kumuh kawasan pesisir perlu dilakukan uji F.

Analisis uji - F pada dasarnya menunjukkan apakah semua variabel independen yang dimasukkan dalam model mempunyai pengaruh secara bersama-sama terhadap variabel dependen. Dengan ketentuan $\mathrm{Ha}=$ signifikan, sedangkan Ho = tidak signifikan.

Tabel 3 Ringkasan Anova untuk Menguji Keberartian Regresi

\begin{tabular}{cccccc}
\hline $\begin{array}{c}\text { Sumber } \\
\text { Variasi }\end{array}$ & JK & Dk & RJK & F Hitung & F Tabel \\
\hline Regresi & 4,1066562 & 3 & 1,026664 & $\mathbf{6 , 6 8 3 *})$ & $\mathbf{2 , 4 7}$ \\
Sisa & 14,438798 & 129 & 0,153604 & - & \\
\hline Total & $\mathbf{1 8 , 5 4 5 4 5}$ & $\mathbf{1 3 2}$ & - & - & \\
\hline
\end{tabular}


Dari hasil perhitungan diatas $\alpha=5 \%, \mathrm{dk}=\mathrm{n}-\mathrm{k}(133-3=130)$.

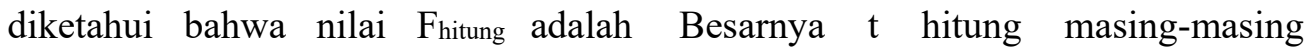
6,683 dan nilai $F_{\text {tabel }}$ adalah 2,47. Harga variabel dapat dilihat pada Tabel Fhitung selanjutnya dikonsultasikan berikut :

dengan $\mathrm{F}_{\text {tabel }}$ dengan derajat kebebasan (dk) pembilang $=3 \mathrm{dan} \mathrm{dk}$ penyebut $=$ 129 untuk taraf signifikansi 5\%, diperoleh $\quad \mathrm{F}_{\text {tabel }}=2,47$. Dengan demikian, nilai $\mathrm{F}_{\text {hitung }}=6,683>$ dari nilai $\mathrm{F}_{\text {tabel }}$ pada taraf signifikan $5 \%=$ 2,47. Maka dengan demikian dari hasil analisis tersebut bahwa faktor lingkungan, faktor sosial, dan faktor ekonomi terdapat pengaruh yang signifikan, artinya ketiga faktor tersebut secara bersama-sama memberikan pengaruh yang signifikan terhadap permukiman kumuh di kawasan pesisir Kelurahan Tallo.

\section{Hasil Uji t}

Analisis uji-t digunakan untuk menguji apakah variabel bebas secara parsial atau individual berpengaruh terhadap permukiman kumuh di kawasan pesisir. Dengan dilakukan uji$\mathrm{t}$ ini akan dapat diketahui apakah variabel lingkungan, sosial, dan ekonomi terhadap permukiman kumuh di kawasan pesisir.

Pengujian dengan cara membandingkan antara $t$ tabel dengan $t$ hitung. Mencari t tabel dengan kriteria

Tabel 4 Hasil Pengujian t

\begin{tabular}{lcc}
\hline \multicolumn{1}{c}{ Variabel Bebas } & t - Hitung & t - Tabel \\
\hline Lingkungan & 4,386 & 1,985 \\
Sosial & 3,560 & 1,985 \\
Ekonomi & 2,299 & 1,985 \\
\hline
\end{tabular}

Dari tabel di atas didapat nilai t tabel adalah 1,985 . Karena $\mathrm{t}$ hitung $>\mathrm{t}$ tabel maka Ho ditolak dan Ha diterima, artinya secara parsial atau individual ketiga variabel tersebut masing-masing berpengaruh secara signifikan terhadap permukiman kumuh di kawasan pesisir dengan besaran pengaruh yang berbeda-beda. Faktor yanga paling besar memberikan pengaruh terhadap kawasan pesisir adalah lingkungan dengan nilai t hitung 4,336; kemudian yang kedua faktor sosial dengan nilai $\mathrm{t}$ hitung sebesar 3,560; dan yang terakhir faktor ekonomi dengan nilai $\mathrm{t}$ hitung 2,299 .

Konsep dan Strategi Penanganan Permukiman Kumuh Dalam Upaya Meminimalisir Dampaknya Terhadap Kawasan Pesisir Kelurahan Tallo

\section{A. Konsep Penanganan}

Permukiman Kumuh 
Konsep penanganan permukiman kumuh terdiri atas 2 (dua) yaitu konsep pencegahan dan konsep peningkatan kualitas lingkungan.

Pencegahan.

Kegiatan

pencegahan dilaksanakan melalui, dua kegiatan yaitu, pengawasan dan pengendalian: terutama dilakukan oleh pemerintah daerah mencakup kesesuaian terhadap perizinan, standar teknis dan pemeriksaan sesuai dengan peraturan perundang-undangan; dan pemberdayaan masyarakat: melakukan kegiatan pemberdayaan kepada masyakat melalui pelaksanaan melalui pendampingan dan pelayanan informasi. Bisa dikatakan Program Kotaku secara umum masuk dalam kategori penanganan kawasan kumuh ini.

Peningkatan

Kualitas

\section{Lingkungan}

Permukiman.

Kegiatan pencegahan dilaksanakan melalui 4 kegiatan yaitu pemugaran, pembangunan baru, peningkatan kapasitas kelembagaan masyarakat dan pengembangan usaha ekonomi masyarakat. Dalam upaya peningkatan kualitas terhadap permukiman kumuh, pemerintah daerah menetapkan kebijakan secara holistik, penyelenggaraan penanganan permukiman kumuh harus dilakukan secara multisectoral karena memerlukan koordinasi dengan berbagai bidang lain yang terkait dengan kegiatan penanganan kumuh tidak dapat ditangani oleh satu sektor sajakarena merupakan tanggungjawab semua stakeholder terkait.

\section{B. Strategi Penanganan}

\section{Permukiman Kumuh}

Strategi penanganan permukiman kumuh dalam upaya meminimalisir dampak permukiman kumuh di kawasan pesisir kelurahan Tallo dilakukan dengan sasaran aspek lingkungan, aspek sosial dan aspek ekonomi. Untuk lebih jelasnya diuraikan sebagai berikut :

1. Peningkatan kualitas lingkungan kawasan permukiman kumuh

2. Penertiban IMB, Pembatasan pembangunan hunian, Bantuan perbaikan rumah tidak layak huni.

3. Perbaikan infrastruktur permukiman dan penyediaan sarana prasarana penunjang permukiman kumuh 
4. Penataan kawasan permukiman yang bersinergi dengan keberadaan Kawasan fungsional strategis

5. Pengendalian dampak pencemaran lingkungan dengan memberlakukan aturan bersama di tingkat masyarakat.

6. Peningkatan partisipasi masyarakat dalam pembangunan

7. Terbangunnya tolerasi dalam masyarakat berdasarkan nilai-nilai sebagai modal sosial dalam pembangunan

8. Penyediaan infrastruktur ekonomi untuk mendukung produktivitas masyarakat.

9. Pengembangan daerah untuk kegiatan industri rumah tangga dengan pemanfaatan sumber daya manusia lokal, sehingga mampu meningkatkan taraf hidup masyarakat dan mengurangi pengangguran.

\section{KESIMPULAN}

Berdasarkan uraian pada pembahasan bab-bab sebelumnya dan sesuai dengan data-data yang diperoleh selama penelitian, maka kesimpulan akhir yang dapat diambil adalah sebagai berikut :

1. Faktor-faktor yang mempengaruhi dampak permukiman kumuh terhadap kawasan pesisir Kelurahan Tallo yaitu Faktor Lingkungan, Faktor Sosial dan Faktor Ekonomi.

2. Konsep penanangan permukiman kumuh di kawasan pesisir Kelurahan Tallo yaitu 1). Konsep Pencegahan (pengawasan, pengendalian \& pemberdayaan masyarakat) dan 2). Konsep Peningkatan kualitas lingkungan (pemugaran \& pembangunan baru) sedangkan strategi penanganannya yaitu dengan sasaran aspek lingkungan, aspek sosial dan aspek ekonomi.

\section{SARAN}

1. Pemerintah sebagai pengambil kebijakan harusnya bisa menjadi nakhoda dalam perencanaan, maka perlu adanya perhatian lebih dari pemerintah khususnya Pemerintah Kelurahan dan Pemerintah Kecamatan terhadap tumbuh kembangnya permukiman kumuh di Kelurahan Tallo. Ketegasan dan pengawasan dalam pemberian izin membangun khususnya di wilayah pesisir sangat diperlukan agar tumbuh kembangnya bangunan hunian yang tidak sesuai persyaratan teknis dapat terkendali. 
2. Bagi peneliti selanjutnya diharapkan dapat mengembangkan penelitian ini dengan melakukan penelitian yang lebih mendalam tentang seberapa besar tingkat pencemaran lingkungan di kawasan pesisir oleh keberadaan permukiman kumuh.

\section{UCAPAN TERIMA KASIH}

Penulis mengucapkan terima kasih kepada pihak Program Kota Tanpa Kumuh (Kotaku) dan Pemerintah Kelurahan Tallo serta Masyarakat Pesisir Kelurahan Tallo yang telah memberikan dukungan berupa izin dalam pengumpulan data-data penelitan, serta para pembimbing dan para reviewer yang telah banyak memberikan masukan dan komentar untuk memperbaiki tulisan ini.

\section{DAFTAR PUSTAKA}

Dahuri, Rokhmin. 2003. Keanekaragaman Hayati Laut ; Aset Pembangunan Berkelanjutan Indonesia. Gramedia Pustaka Utama : Jakarta

Kuswartojo, Tjuk. 2005. Perumahan dan Permukiman di Indonesia. ITB : Bandung.

Hartono. 2012. Statistik Untuk Penelitian. Pustaka Pelajar : Jogjakarta.

Adisasmita, $\quad$ Rahardjo. 2008 Pengembangan Wilayah; Konsep Dan Teori. Graha Ilmu : Yogyakarta.
Sugiyono. 2011. Metode Penelitian Kuantitatif Kualitatif Dan R\&D. Alfabeta : Bandung.

Direktorat Jenderal Perumahan dan Permukiman. 2002. Konsep Panduan Identifikasi Kawasan Perumahan dan Permukiman Kumuh.

Undang - Undang No. 1. 2011. Perumahan dan Kawasan Permukiman.

Peraturan Menteri PUPR No. 2. 2016. Peningkatan Kualitas Terhadap Lingkungan Perumahan dan Permukiman Kumuh.

Dokumen Slum Improvement Action Plan (SIAP) Program KOTAKU Tahun 2016.

Rencana Tata Ruang Wilayah (RTRW) Kota Makassar Tahun 2015-2034.

Endang, Eni. 2006. Jurnal : Faktor-Faktor Yang Mempengaruhi Terciptanya Kawasan Permukiman Kumuh Di Kawasan Pusat Kota.

Kadir, Ishak. 2010. Jurnal : Studi Karakteristik dan Pola Penanganan Kawasan Kumuh Kota Bau-bau.

Putro, Jawas Dwijo. 2011. Jurnal : Penataan Kawasan Permukiman Kumuh Pinggiran Sungai di Kecamatan Sungai Raya.

Amri, Nurmaida. 2012. Jurnal : Karakteristik Lingkungan Permukiman Kumuh Tepian Sungai Kecamatan Kolaka. Universitas Hasanuddin,

Ayu, Marina. 2013. Jurnal : Tipologi Kerentanan Permukiman Kumuh 
Kawasan Pesisir Terhadap

Perubahan Iklim Di Kota Tegal.

Pramudyanto, Bambang. 2014. Jurnal : Pengendalian Pencemaran dan Kerusakan di Wilayah Pesisir.

Pradika, Erga. 2014. Jurnal : Pengaruh Pembangunan Rusunawa Kyai Mojo Terhadap Penanganan Permukiman Kumuh Di Kawasan Pesisir. Universitas Gajah Mada

Pratiwi, Trisakti. 2015. Jurnal : Analisis Keberadaan Permukiman Kumuh di Bantaran Sungai Kelurahan Buloa Kecamatan Tallo Kota Makassar. Universitas 45.
Yermia, Joel. 2016. Jurnal : Ketersediaan Infrastruktur Permukiman Kumuh Pesisir Desa Likupang. Universitas Sam Ratulangi.

Mirtaciana, Ariane. 2016. Tesis : Evaluasi Kegiatan Penanganan Permukiman Kumuh Tepi Sungai Di Kampung Pulau Pandan. Universitas Gajah Mada.

Yulianti, P Bani. 2015. Tesis : Evaluasi Penataan Kawasan Permukiman Kumuh Kawasan Tegalpanggung. Universitas Gajah Mada.

Ashar, Muhammad. 2010. Tesis : Persepsi Masyarakat Terhadap Permukiman Kumuh. Universitas Gajah mada. 